\title{
The Influence of Titanium Additions and Interpass Temperature on the Microstructures and Mechanical Properties of High Strength SMA Weld Metals
}

\author{
M. Q. JOHNSON, G. M. EVANS ${ }^{1)}$ and G. R. EDWARDS
}

Center for Welding, Joining, and Coatings Research, Colorado School of Mines, Golden, Colorado 80401, U.S.A.

1) Oerlikon-Welding Ltd., Birchstrasse 230, Zurich, Switzerland $\mathrm{CH}-8050$.

(Received on May 15, 1995; accepted in final form on June 19, 1995)

\begin{abstract}
The influence of titanium additions and interpass temperature on the microstructures and properties in low carbon-1.5Mn-3Ni-0.5Mo multiple pass steel weld metals produced using the shielded metal arc welding (SMAW) process was studied. Robust weld metals with high strength ( $>690 \mathrm{MPa}$ ) and toughness $(100 \mathrm{~J}$ at $-70^{\circ} \mathrm{C}$ ) were produced when titanium concentrations of 180 to $400 \mathrm{ppm}$ were added to a base chemical composition of low carbon-1.5Mn-3Ni-0.5Mo steels. High toughness was measured in weld metals containing either 30 to $90 \mathrm{ppm}$ titanium or 180 to $400 \mathrm{ppm}$ titanium while deteriorated weld metal toughness was observed when weld metal titanium concentrations were less than $10 \mathrm{ppm}, 90$ to $180 \mathrm{ppm}$, or more than $400 \mathrm{ppm}$. The microstructures of these low carbon weld metals were complex. The difference between the classification systems used for weld metals and base metals was addressed.
\end{abstract}

KEY WORDS: high strength steel weld metal; multiple pass weld metal; shielded metal arc weld metal; titanium concentration; HSLA; interpass temperature; acicular ferrite.

\section{Introduction}

The increasing use of high strength steel for applications such as naval vessels, offshore platform construction, and heavy equipment requires the development of shielded metal arc welding consumables capable of depositing weld metal with high strengths (yield strength greater than $600 \mathrm{MPa}$ ) and high toughness (CVN energy greater than $27 \mathrm{~J}$ at $-51^{\circ} \mathrm{C}$ for $\mathrm{E} 10018$ type electrodes). ${ }^{1)}$ Based on a simple Hall-Petch relationship, the upper strength limit of acicular ferrite weld metals is less than $600 \mathrm{MPa}(87 \mathrm{ksi}) .{ }^{2)}$ Higher strength levels (yield strengths greater than $690 \mathrm{MPa}$ ) have been achieved in weld metals with mixed microstructures of low carbon martensite, bainite, and acicular ferrite using SAW, GMAW, and FCAW. ${ }^{2-9)}$ Only a few studies ${ }^{10,11)}$ have investigated high strength steel weld metals produced using the SMAW process.

Numerous investigations have shown that the presence of large fractions of acicular ferrite produces excellent weld metal impact properties. ${ }^{12-19)}$ Similar observations have been made from mechanical testing of the grain-coarsened heat affected zone (HAZ) of titanium deoxidized steel, ${ }^{20-22)}$ where finely dispersed titanium oxide inclusions may promote formation of acicular ferrite. The resulting fracture toughness of these regions is less affected by weld cooling rate. While weld metals with microstructures containing large fractions of acicular ferrite are relatively insensitive to minor variations in chemical composition and welding variables, higher strength steel weld metals with mixed microstructures are sensitive to minor changes in weld metal chemical composition and cooling rate.

With the higher alloy concentrations found in HSLA weld metals, higher oxygen concentrations ( $<600 \mathrm{ppm})$ and thus smaller prior austenite grains do not reduce the toughness of the weld metal by the formation of continuous films of grain boundary ferrite. Furthermore, in addition to the high alloy concentrations found in HSLA weld metals, the fast cooling rates associated with the SMAW process favor the formation of mixed martensitic, bainitic, and acicular ferrite microstructures.

The successful welding of HSLA steels generally requires the consideration of a preheat. The need for preheating increases with increasing carbon and alloy concentrations and with increasing steel thickness. Minimum preheat and interpass temperatures for HSLA and HSLA Q\&T (quenched and tempered) steels range from 20 to $205^{\circ} \mathrm{C}^{23,24)}$ To reduce production costs, reduction or elimination of preheating and maintenance of an interpass temperature are being considered. Weld metals which will not crack when deposited at low preheat/interpass temperatures with highly restrained joints would reduce fabrication costs considerably.

The present investigation was undertaken with the objective of determining the effects of titanium additions to high strength low carbon-1.5Mn-3Ni-0.5Mo weld metals. A secondary objective was to study the influence 
of interpass temperature (cooling rate) on the mechanical properties found in all-weld-metal deposits produced by the SMAW process. This type of information is essential to the continuing efforts to develop consumables for high strength applications.

\section{Materials and Experimental Procedure}

\subsection{Weld Preparation}

Twenty-eight basic type electrodes were prepared by progressively increasing the titanium metal concentrations in the coating, up to a maximum of $7 \%$. Nickel and molybdenum were added to provide increased strength relative to $\mathrm{C}-1.5 \mathrm{Mn}$ welds produced in earlier investigations. ${ }^{25,26)}$ The nominal chemical composition of the weld metals was (in wt $\%$ ) $0.06 \mathrm{C}-1.5 \mathrm{Mn}-3.2 \mathrm{Ni}-$ $0.5 \mathrm{Mo}-0.3 \mathrm{Si}$ with titanium concentrations ranging from less than $0.001 \mathrm{wt} \%(10 \mathrm{ppm})$ to $0.10 \mathrm{wt} \%(1000 \mathrm{ppm})$. Other microalloying elements such as boron, niobium, aluminum, and vanadium were held at trace levels. Weld metal chemical compositions were analyzed using ICP-AES and various Leco analyzers. The core wire was four millimeters in diameter, and the coating factor $(D / d)$ was 1.68 .

Multiple-pass SMA welds were deposited as specified in the ISO-2560-1973 specification. ${ }^{27)}$ Welding was done in the flat position and three beads per layer were deposited. A total of twenty-seven runs were required to fill the joint. Direct-current-electrode-positive polarity was used to deposit the weld metal with a current of $170 \mathrm{~A}$, a voltage of $21 \mathrm{~V}$, and a travel speed of $3.6 \mathrm{~mm} \mathrm{~s}^{-1}$, resulting in a nominal heat input of $1 \mathrm{~kJ} / \mathrm{mm}$. Similar to a previous investigation ${ }^{28)}$ using $\mathrm{C}-\mathrm{Mn}$ weld metals, the weld metal cooling rate was varied by depositing weld metals using interpass temperatures of $25,150,240$, and $300^{\circ} \mathrm{C}$, as measured by point contact at the mid-length position. A duplicate series of welds were deposited using the $150{ }^{\circ} \mathrm{C}$ interpass temperature to verify trends in toughness, extend the weld metal titanium concentrations, and indicate the magnitude of experimental error in the multiple pass welds.

\subsection{Mechanical Testing}

All weld metal tensile specimens were machined, given a hydrogen removal treatment at $250^{\circ} \mathrm{C}$ for $14 \mathrm{~h}$, and tested at room temperature for each of the 28 multiple pass welds produced. Approximately 18 Charpy-V notch specimens were tested for each of the multiple pass welds to obtain full transition curves.

\subsection{Metallography}

Weld metal microstructures in the CVN region were examined using optical microscopy. Specifically, the high temperature reheated zones located in the CVN region were studied. Samples were etched in $2 \%$ nitric acid in alcohol and photographed at a magnification of $800 \mathrm{X}$.

\section{Results and Discussion}

\subsection{Weld Metal Chemical Composition}

Considering that the welds were produced using the shielded metal arc welding process, weld metal chemical compositions were remarkably consistent. As shown in Table 1, the weld metal chemical compositions of the 28 shielded metal arc weld metals did not vary substantially; i.e., carbon varied from 0.044 to $0.066 \mathrm{wt} \%$, manganese from 1.43 to $1.72 \mathrm{wt} \%$, nickel from 3.22 to $3.56 \mathrm{wt} \%$, molybdenum from 0.45 to $0.48 \mathrm{wt} \%$, and nitrogen from 62 to $98 \mathrm{ppm}$. This compositional consistency resulted in

Table 1. Chemical composition of experimental weld metals.

\begin{tabular}{|c|c|c|c|c|c|c|c|c|c|c|c|c|}
\hline $\begin{array}{l}\text { Interpass } \\
\text { Temp }{ }^{\circ} \mathrm{C}\end{array}$ & $\begin{array}{c}\text { C } \\
\text { wt.pet. }\end{array}$ & $\begin{array}{c}\text { Mn } \\
\text { wt.pct. } \\
\end{array}$ & $\begin{array}{c}\text { Si } \\
\text { wt.pct. }\end{array}$ & $\begin{array}{c}\mathrm{S} \\
\text { wt.pct. }\end{array}$ & \begin{tabular}{c|}
$P$ \\
wt.pct.
\end{tabular} & 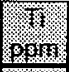 & $\begin{array}{c}\mathrm{N} \\
\mathrm{ppm} \\
\end{array}$ & \begin{tabular}{|c|}
0 \\
$\mathrm{ppm}$ \\
\end{tabular} & $\begin{array}{c}\mathrm{Ni} \\
\text { wt.pct. }\end{array}$ & $\begin{array}{c}\text { Mo } \\
\text { wt pct. }\end{array}$ & $\begin{array}{c}\text { Pcm } \\
\text { wt. pct. }\end{array}$ & $\begin{array}{c}\mathrm{Ti}(\text { Coat }) \\
\%\end{array}$ \\
\hline \multirow{5}{*}{25} & 0.043 & 1.64 & 0.35 & 0.005 & 0.008 & \%. & 64 & 402 & 3.45 & 0.47 & 0.229 & 0 \\
\hline & 0.050 & 1.61 & 0.35 & 0.006 & 0.008 & 16 & 98 & 380 & 3.30 & 0.47 & 0.231 & 0.5 \\
\hline & 0.054 & 1.48 & 0.29 & 0.006 & 0.008 & 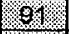 & 87 & 341 & 3.31 & 0.44 & 0.225 & 1.5 \\
\hline & 0.051 & 1.59 & 0.39 & 0.006 & 0.007 & $2 / 20$ & 75 & 234 & 3.38 & 0.46 & 0.233 & 4 \\
\hline & 0.055 & 1.67 & 0.40 & 0.004 & 0.008 & 530 & 69 & 257 & 3.40 & 0.47 & 0.243 & 5.7 \\
\hline \multirow{5}{*}{150} & 0.043 & 1.58 & 0.32 & 0.006 & 0.008 & W & 84 & 414 & 3.56 & 0.46 & 0.226 & 0 \\
\hline & 0.044 & 1.60 & 0.34 & 0.005 & 0.008 & 4. & 77 & 340 & 3.29 & 0.46 & 0.224 & 0.5 \\
\hline & 0.045 & 1.58 & 0.30 & 0.005 & 0.008 & 95 & 87 & 273 & 3.45 & 0.46 & 0.225 & 1.5 \\
\hline & 0.051 & 1.49 & 0.33 & 0.004 & 0.007 & ช60 & 92 & 268 & 3.41 & 0.46 & 0.227 & 4 \\
\hline & 0.056 & 1.65 & 0.38 & 0.004 & 0.008 & 60 & 65 & 247 & 3.38 & 0.46 & 0.241 & 5.7 \\
\hline \multirow{8}{*}{150} & 0.049 & 1.60 & 0.30 & 0.006 & 0.011 & 6 & 74 & 515 & 3.32 & 0.45 & 0.227 & 0 \\
\hline & 0.047 & 1.59 & 0.32 & 0.006 & 0.010 & (8) & 80 & 445 & 3.26 & 0.45 & 0.224 & 0.5 \\
\hline & 0.050 & 1.66 & 0.33 & 0.006 & 0.011 & 83. & 81 & 430 & 3.27 & 0.46 & 0.232 & 1.2 \\
\hline & 0.052 & 1.67 & 0.32 & 0.006 & 0.010 & 142 & 83 & 385 & 3.31 & 0.48 & 0.236 & 1.8 \\
\hline & 0.051 & 1.62 & 0.36 & 0.005 & 0.011 & 44 & 83 & 350 & 3.24 & 0.47 & 0.232 & 2.4 \\
\hline & 0.054 & 1.55 & 0.32 & 0.004 & 0.009 & 280 & 84 & 290 & 3.54 & 0.47 & 0.235 & 4.8 \\
\hline & 0.059 & 1.66 & 0.44 & 0.004 & 0.009 & 药 & 86 & 265 & 3.26 & 0.47 & 0.245 & 6 \\
\hline & 0.066 & 1.66 & 0.43 & 0.003 & 0.010 & 6000 & 65 & 250 & 3.22 & 0.47 & 0.251 & 7 \\
\hline \multirow{5}{*}{240} & 0.043 & 1.62 & 0.31 & 0.006 & 0.008 & \% & 75 & 400 & 3.44 & 0.47 & 0.226 & 0 \\
\hline & 0.043 & 1.64 & 0.34 & 0.005 & 0.008 & 46 & 77 & 351 & 3.33 & 0.47 & 0.226 & 0.5 \\
\hline & 0.046 & 1.43 & 0.25 & 0.005 & 0.007 & $8 \%$ & 73 & 278 & 3.31 & 0.44 & 0.213 & 1.5 \\
\hline & 0.053 & 1.52 & 0.33 & 0.005 & 0.007 & 2.20 & 72 & 272 & 3.35 & 0.46 & 0.229 & 4 \\
\hline & 0.054 & 1.72 & 0.40 & 0.003 & 0.007 & (486) & 74 & 251 & 3.44 & 0.46 & 0.244 & 5.7 \\
\hline \multirow{5}{*}{300} & 0.040 & 1.55 & 0.30 & 0.005 & 0.007 & 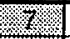 & 62 & \begin{tabular}{|l|}
412 \\
\end{tabular} & 3.28 & 0.47 & 0.217 & 0 \\
\hline & 0.041 & 1.58 & 0.31 & 0.005 & 0.008 & \% & 62 & 389 & 3.37 & 0.47 & 0.221 & 0.5 \\
\hline & 0.043 & 1.53 & 0.30 & 0.005 & 0.008 & 08 & 64 & 333 & 3.39 & 0.48 & 0.221 & 1.5 \\
\hline & 0.049 & 1.53 & 0.37 & 0.004 & 0.007 & 240 & 75 & 275 & 3.34 & 0.46 & 0.227 & 4 \\
\hline & 0.053 & 1.63 & 0.38 & 0.003 & 0.007 & 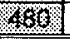 & 69 & 253 & 3.28 & 0.48 & 0.237 & 5.7 \\
\hline
\end{tabular}




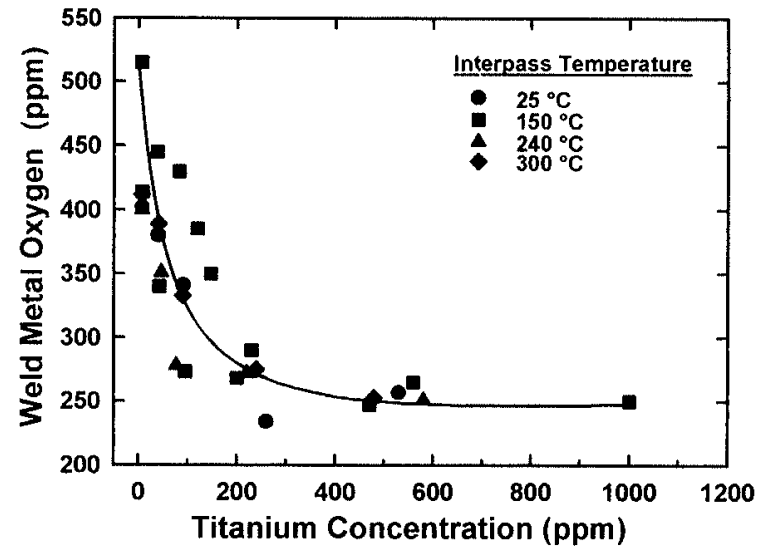

Fig. 1. Relationship between weld metal titanium and oxygen concentrations.

an Ito-Bessyo carbon equivalent, $\mathrm{P}_{\mathrm{cm}}{ }^{29)}$ which varied over a narrow range of 0.22 to $0.25 \mathrm{wt} \%$. The small increase in $P_{\mathrm{cm}}$ was due almost entirely to the small drift in carbon caused by increasing titanium additions to the coating. Based on a previous investigation, ${ }^{30)}$ this small difference in carbon concentration is not expected to influence the mechanical properties when compared to the effects of increasing titanium and reducing oxygen. Table 1 also shows that boron, vanadium, niobium, aluminum, chromium, and copper concentrations were maintained at trace levels. Titanium additions to the coating (ranging from 0 to $7 \%$ ) increased titanium concentrations in the weld metal (ranging from 6 to $1000 \mathrm{ppm}$ ), and effectively deoxidized the weld metal.

Figure 1 shows the relationship between weld metal titanium concentration and weld metal oxygen concentration. Weld metal oxygen concentration decreased from 520 to $300 \mathrm{ppm}$ when weld metal titanium concentration increased from 6 to approximately $100 \mathrm{ppm}$. Further increases in titanium reduced weld metal oxygen concentrations an additional $50 \mathrm{ppm}$.

\subsection{Weld Metal Cooling Rates}

Chemical composition and cooling rate are two variables that strongly influence weld metal microstructures and thus mechanical properties. In this investigation, variations of the interpass temperature produced variations in the cooling rate. For a constant heat input, increasing interpass temperature results in an corresponding decrease in weld metal cooling rate. For welding of low alloy steel, the cooling time between 800 and $500^{\circ} \mathrm{C}\left(\Delta t_{8 / 5}\right)$ is widely accepted as an adequate index for the thermal conditions under which the decomposition of austenite and subsequent competitive phase transformations take place. The time to cool from 800 to $500^{\circ} \mathrm{C}$ can be calculated from the first order solution given by Rosenthal for thick plates, ${ }^{31)}$ assuming that heat flow in the direction of travel $(x)$ is negligible compared to the perpendicular direction, and substituting $t=x / v$. For the given assumptions, the solution for $\Delta t_{8 / 5}$ can be related to both the heat input $(E)$ and preheat/interpass temperatures $\left(T_{0}\right)$, by the following equations. ${ }^{32-35)}$

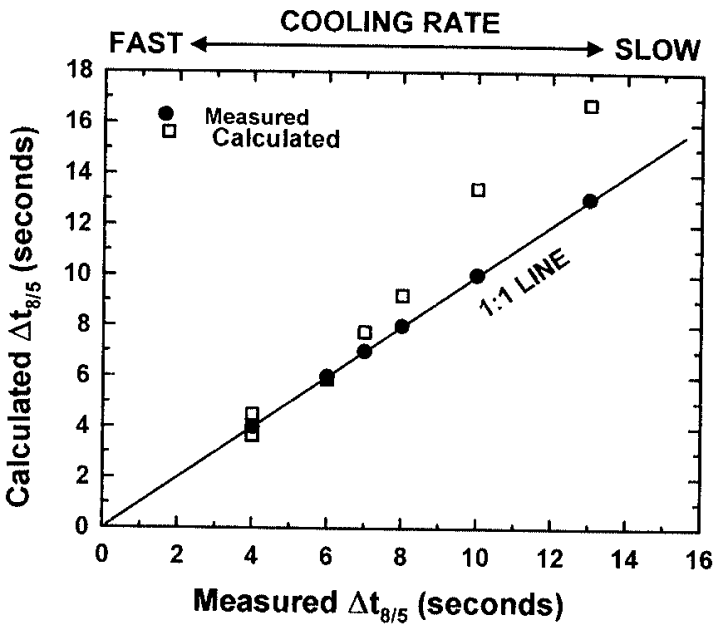

Fig. 2. Measured ${ }^{28,36)}$ and calculated values of $\Delta t_{8 / 5}$.

$$
\Delta t_{8 / 5}(\mathrm{~s})=\frac{E \eta}{2 \pi \lambda}\left[\frac{1}{\left(500-T_{0}\right)}-\frac{1}{\left(800-T_{0}\right)}\right]
$$

In Eq. (1), $\eta$ is the arc efficiency factor, $T_{0}$ is the interpass temperature $\left({ }^{\circ} \mathrm{C}\right), \lambda$ is the thermal conductivity ( $\mathrm{W} \mathrm{mm} \mathrm{m}^{-1}{ }^{\circ} \mathrm{C}^{-1}$ ), and $E\left(\mathrm{~kJ} \mathrm{~mm}^{-1}\right)$ is the nominal heat input per unit length of the weld metal, defined as:

$$
E=\frac{V I}{1000 v}
$$

In this expression, $V$ is voltage (Volts), $I$ is current (Amperes), and $v$ is travel speed $\left(\mathrm{mm} \mathrm{s}^{-1}\right)$.

Using Eqs. (1) and (2), cooling rate can be related to both the heat input and interpass temperature. In a previous study using identical welding process variables and conditions, Evans ${ }^{28)}$ reported $\Delta t_{8 / 5}$ to be $4,6,8$, and $10 \mathrm{sec}$ corresponding to welds produced using a nominal heat input of $1 \mathrm{~kJ} / \mathrm{mm}$ and interpass temperatures of 20 , 150,240 , and $300^{\circ} \mathrm{C}$ respectively. Assuming an arc efficiency of 0.70 and a constant thermal conductivity of $0.025 \mathrm{~W} \mathrm{~mm}^{-1}{ }^{\circ} \mathrm{C}^{-1},{ }^{35)}$ the time to cool from 800 to $500^{\circ} \mathrm{C}$ was calculated as shown in Fig. 2. In addition to the data from variations in interpass temperature, ${ }^{28)}$ data from variation in heat input ${ }^{36)}$ are included in Fig. 2 for comparison with calculated values. Figure 2 shows that the calculated values correspond well with the measured values for times less than $9 \mathrm{sec}$. At longer times, the calculated values tend to overestimate $\Delta t_{8 / 5}$. Using Eqs. (1) and (2), an estimate of interpass temperatures and heat inputs required to produce the desired cooling rates was made.

\subsection{Weld Metal Microstructures}

Optical microscopy is commonly used to classify microstructures in steel weld metals. Currently, Commission IX of the International Institute of Welding ${ }^{37)}$ has developed guidelines for the quantification of steel weld metal microstructures. Because the IIW system distinguishes between acicular ferrite and the various side plate structures based on features such as aspect ratio, relative lath size, and number of parallel laths to estimate volume fractions of microconstituents, this system is less complicated than those based solely on transformation 
behavior. ${ }^{38)}$ However, while the IIW system is useful in characterizing classical acicular ferrite microstructures found in medium strength $\mathrm{C}-\mathrm{Mn}$ steel weld metals, ${ }^{39)}$ the application of this system to microstructures found in these low carbon high strength steel weld metals has not been successful because of the varying interpretation and identification of the different microconstituents. ${ }^{39)}$ In base metals, similar difficulties are currently encountered in the classification of ferritic microstructures found in continuously cooled low- and ultralow-carbon steels as recently discussed by Krauss and Thompson. ${ }^{40)}$

In many low-carbon steels, the traditional definitions of bainite ${ }^{41,42)}$ no longer apply because cementite is not associated with intermediate-temperature austenite transformation products. ${ }^{43)}$ In base metal studies, for example, broader classification of bainitic-type microstructures without cementite have been proposed by Ohmori, ${ }^{44,45)}$ Bramfitt and Speer, ${ }^{46)}$ and the ISIJ Bainite Research Group. ${ }^{47,48)}$ The IIW classification violates common terminology based on thermodynamic and kinetic reactions by combining both Widmanstatten ferrite and upper bainite into the FS(A)-constituent (ferrite with aligned second phase). For weld metals, the IIW classification defines acicular ferrite as intragranularly nucleated ferrite grains with aspect ratios of less than $4: 1{ }^{37)}$ In contrast, no definition exists for the intragranularly nucleated ferrite in base metal classification systems. Furthermore, these studies identify ferrite grains with high aspect ratios which nucleate on prior austenite grain boundaries as either acicular ferrite, ${ }^{49,50)}$ or bainitic ferrite $\left(\alpha_{\mathrm{B}}^{\circ}\right){ }^{48)}$ As previously stated, bainitic ferrite (as classified in base metal literature) would be referred to as FS(A) in the IIW classification system. The debate concerning the mechanisms of formation (with respect to the relative importance of shear and diffusion) of acicular ferrite in weld metals and of bainitic ferrite in base metals continues and is yet to be resolved.

While the conditions leading to the formation of large fractions of acicular ferrite, and hence good toughness, have been well documented in C-Mn steel weld metals, ${ }^{12)}$ similar approaches fail when the primary microstructure consists of a mixture of acicular ferrite, bainite/bainitic ferrite, and martensite as in the case of high strength steel weld metal. ${ }^{3,10,51,52)}$ Further research is required to determine the mechanisms controlling the competitive phase transformations in these low carbon high strength steel weld metals. Also, terms of microstructural classification consistent with terms found in the base metal literature would be helpful.

Figures 3 to 5 show the effect of variations in titanium concentration and cooling rate on the high temperature reheated weld metal microstructures corresponding to the regions from which the CVN and tensile specimens were extracted. Figures 3 to 5 correspond to weld metals produced with $\Delta t_{8 / 5}$ of 4,6 , and $10 \mathrm{sec}$ (interpass temperatures of 25,150 , and $300^{\circ} \mathrm{C}$ ). The influence of titanium additions on the microstructures is shown in Figs. 3 to 5 for titanium concentrations of approximately $10 \mathrm{ppm}$ or less, $30 \mathrm{ppm}, 110 \mathrm{ppm}, 240 \mathrm{ppm}$, and $400 \mathrm{ppm}$ or more.

Weld metals which were essentially titanium free $(<10 \mathrm{ppm})$ are shown in Figs. 3(a) to 5(a). Mixed microstructures consisting of bainitic ferrite (FS(A)) and granular ferrite $(\mathrm{PF}(\mathrm{I}))$ were observed. Decreasing the cooling rate resulted in a shift from microstructures which were predominantly aligned (Fig 3(a)) to microstructures containing large amounts of granular ferrite (PF(I)). Because of the high alloy concentrations, the formation of primary ferrite $(\mathrm{PF}(\mathrm{G}))$ along austenite grain boundaries was inhibited in all of the weld metals examined in this study.
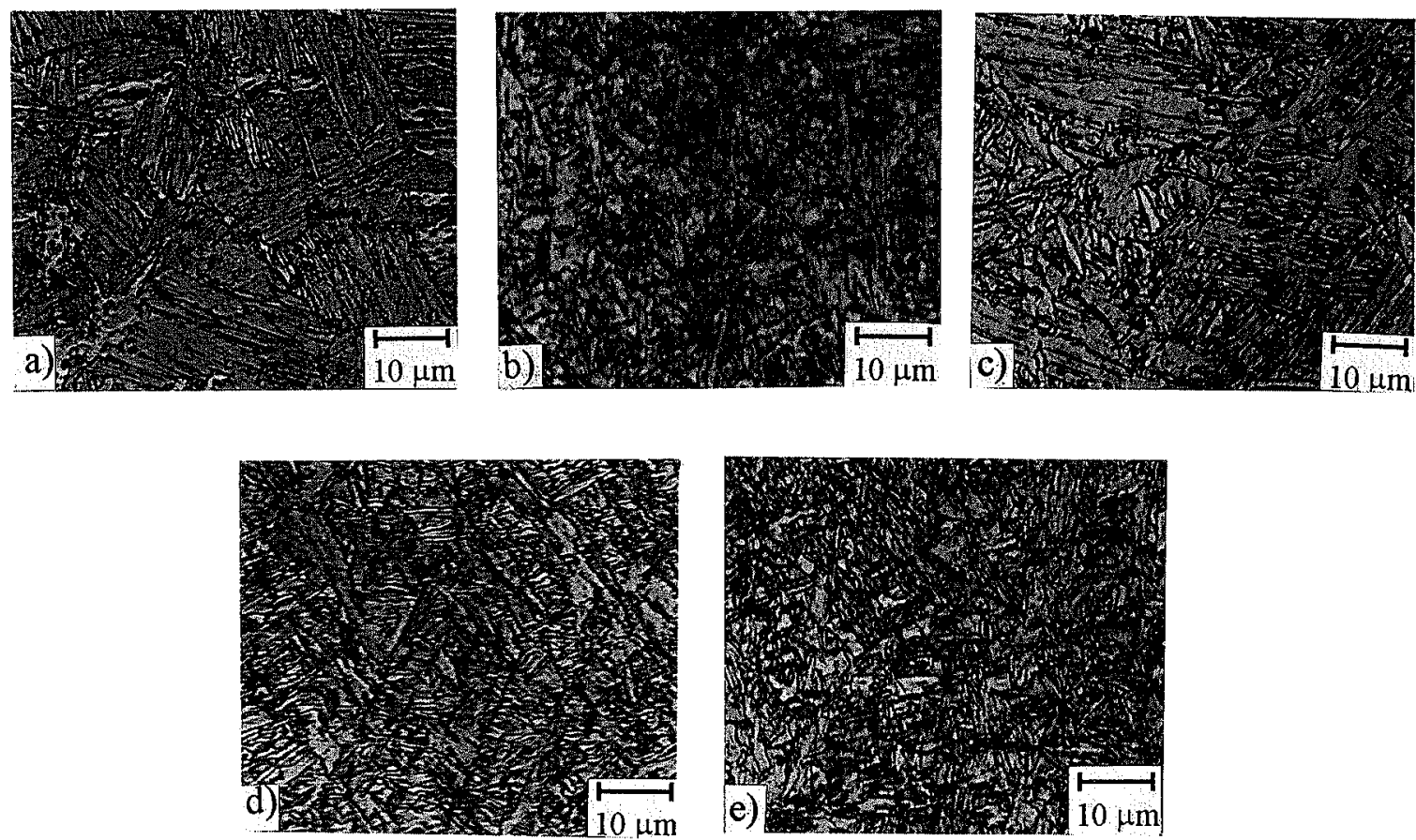

Fig. 3. Weld metal microstructures produced with a cooling rate of $\Delta t_{8 / 5}$ of $4 \mathrm{sec}$ for the following titanium concentrations; a) $7 \mathrm{ppm} \mathrm{Ti}$, b) $40 \mathrm{ppm} \mathrm{Ti}$ c) $91 \mathrm{ppm} \mathrm{Ti}$, d) $260 \mathrm{ppm} \mathrm{Ti}$, e) $530 \mathrm{ppm} \mathrm{Ti}$. 

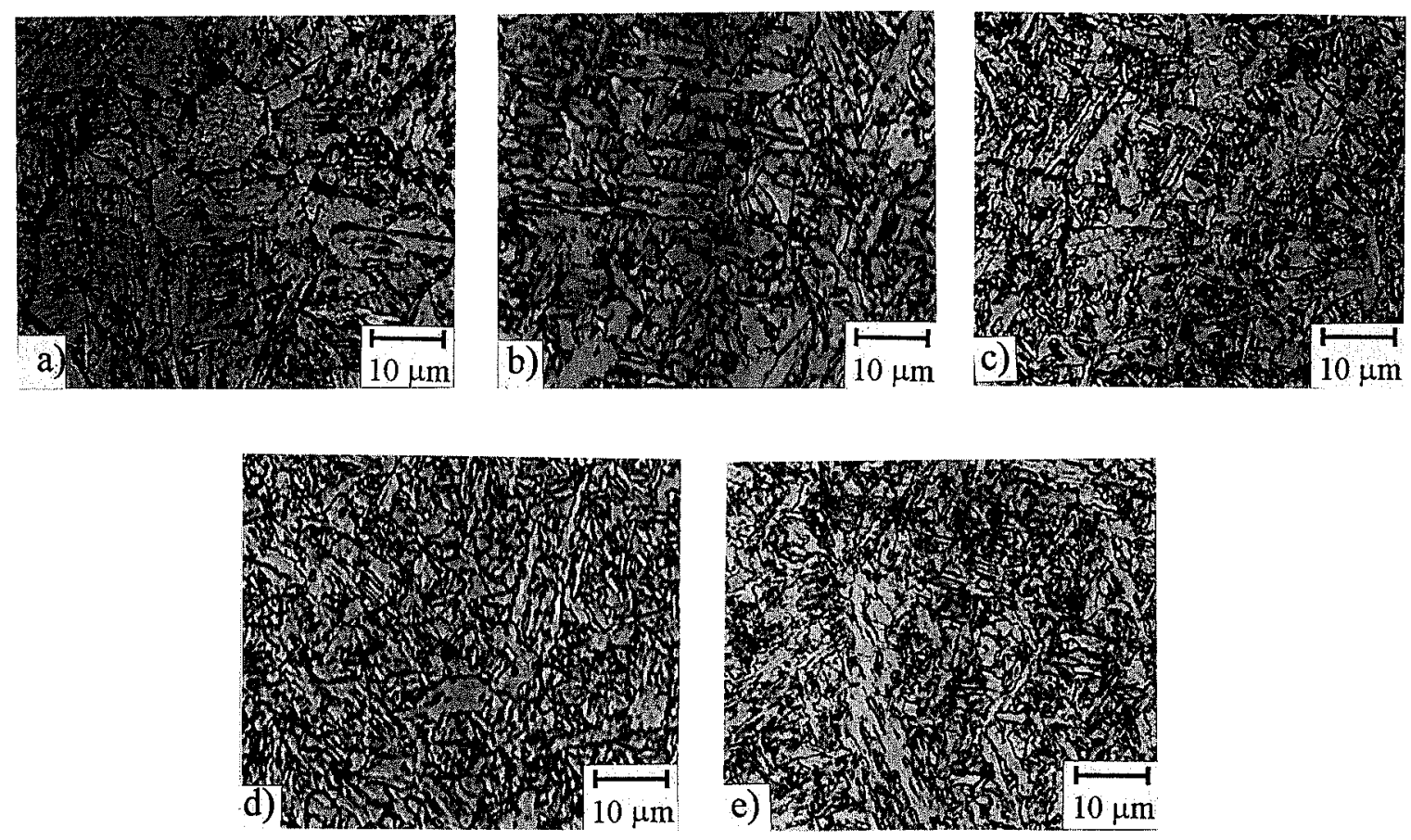

Fig. 4. Weld metal microstructures produced with a cooling rate of $\Delta t_{8 / 5}$ of $6 \mathrm{sec}$ for the following titanium concentrations; a) $7 \mathrm{ppm} \mathrm{Ti}$, b) $42 \mathrm{ppm} \mathrm{Ti}$, c) $95 \mathrm{ppm} \mathrm{Ti}$, d) $200 \mathrm{ppm} \mathrm{Ti}$, e) $470 \mathrm{ppm} \mathrm{Ti}$.
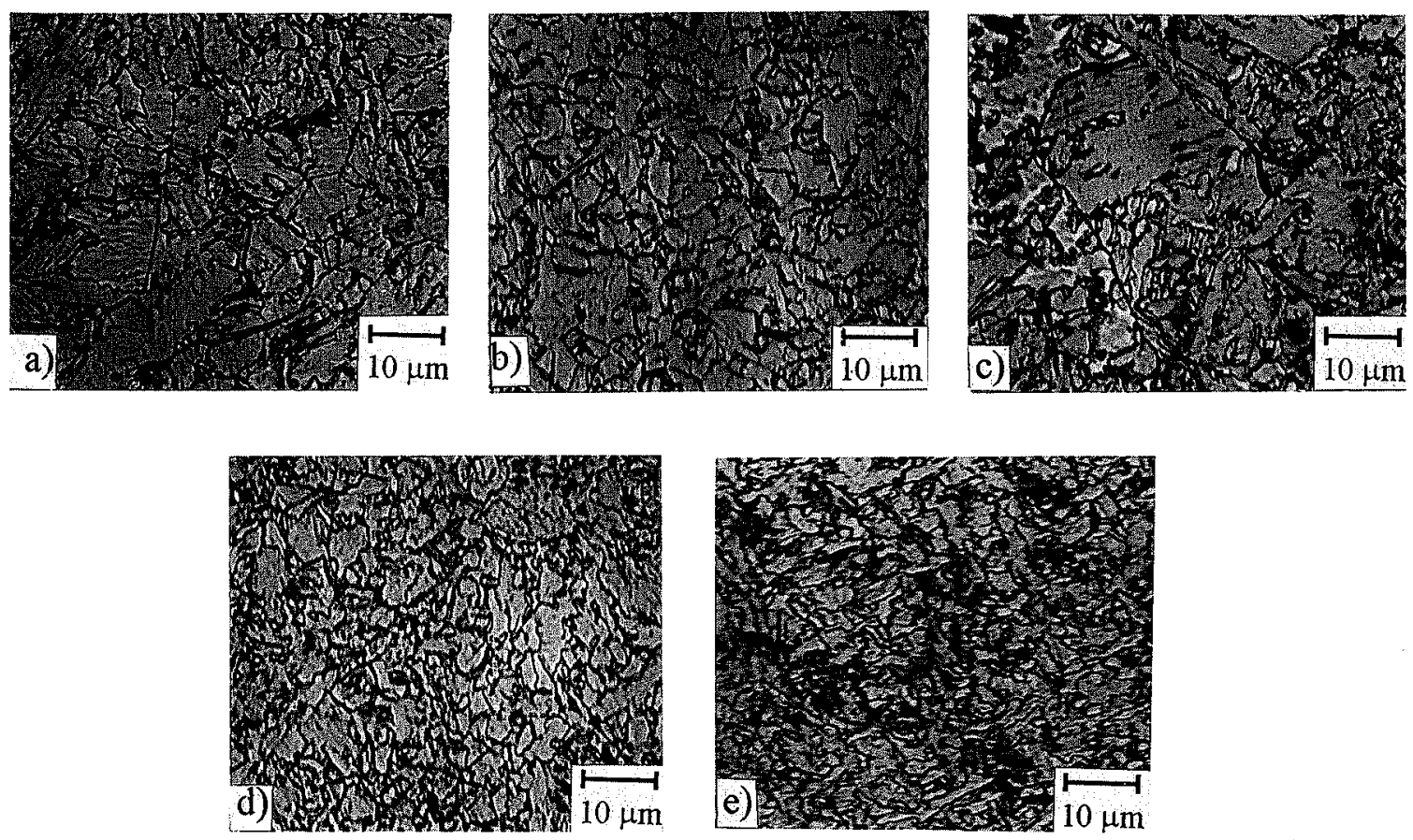

Fig. 5. Weld metal microstructures produced with a cooling rate of $\Delta t_{8 / 5}$ of $10 \mathrm{sec}$ for the following titanium concentrations; a) $7 \mathrm{ppm} \mathrm{Ti}$, b) $41 \mathrm{ppm} \mathrm{Ti}$, c) $90 \mathrm{ppm} \mathrm{Ti}$, d) $240 \mathrm{ppm} \mathrm{Ti}$, e) $480 \mathrm{ppm} \mathrm{Ti}$.

With the introduction of approximately $30 \mathrm{ppm}$ titanium, mixed microstructures of martensite $(M)$, acicular ferrite (AF), bainitic ferrite (FS(A)), and intragranular primary ferrite $(\mathrm{PF}(\mathrm{I}))$ resulted, with the relative fractions of each depending on cooling rate. These microstructures are shown in Figs. 3(b) to $5(\mathrm{~b})$. At high cooling rates, (low $\Delta t_{8 / 5}$ ) a fine low carbon martensite microstructure $(\mathrm{M})$ resulted as shown in Fig. $3(\mathrm{~b})$. With decreasing cooling rates (increasing $\left(\Delta t_{8 / 5}\right)$, acicular ferrite (AF), bainitic ferrite (FS(A)), and granular ferrite $(\mathrm{PF}(\mathrm{I}))$ result as shown in Figs. 4(b) and 5(b). In contrast to the microstructures produced in weld metals containing no titanium, acicular ferrite was present in weld metals containing $30 \mathrm{ppm}$, even at the slowest cooling rates. The amount of bainitic ferrite (FS(A)) was also substantially reduced. The mechanisms of acicular ferrite formation in weld metals containing low titanium concentrations have been previously documented in $\mathrm{C}-\mathrm{Mn}$ weld metals. ${ }^{53-58)}$

Figures 3(c) to 5(c) show that further increases in 
titanium concentration to approximately $90 \mathrm{ppm}$ appear to favor the increased formation of bainitic ferrite (FS(A)) at the expense of acicular ferrite. As with the aforementioned weld metals, decreasing cooling rate results in coarser microstructures with higher temperature transformation products. Similar observations concerning the increase of aligned microstructures in $\mathrm{C}-\mathrm{Mn}$ steels have been made. ${ }^{53)}$ The exact reason for the increased fraction of aligned microphases is unknown, and the cause is difficult to determine based on light microscopy alone; continuing investigations using higher resolution microscopy are ongoing.

Contrary to what was expected, further increases in titanium to approximately $240 \mathrm{ppm}$ resulted in refined microstructures consisting of large fractions of fine acicular ferrite (AF), martensite (M), bainitic ferrite (FS(A)), and granular ferrite (PF(I)) as shown in Figs. 3(d) to 5(d). The acicular ferrite shown in Fig. 4(d) is much finer than the acicular ferrite commonly classified using the IIW system and that reported in $\mathrm{C}-\mathrm{Mn}$ steels. ${ }^{26,53)}$ For this titanium concentration, significant changes in the microstructures did not occur with variations in cooling rates.

Titanium concentrations at levels above $400 \mathrm{ppm}$ resulted in increased inhomogenous banding and precipitation along prior austenite grain boundaries as shown in Figs. 3(e) to 5(e). While the weld metal microstructure produced with the fastest cooling rate was mostly martensitic, decreasing the cooling rate resulted in mixed microstructures of martensite, bainitic ferrite, and acicular ferrite as shown in Figs. 4(e) and 5(e). The formation of granular ferrite does not occur to a great extent, even at slow cooling rates, in these weld metals. The importance of microstructure and titanium concentration will be shown in the following sections.

The reasons for microstructural refinement and insensitivity to cooling rate in weld metals with titanium concentrations in excess of 200 ppm are not readily apparent. However, it is speculated that the formation of TiN may be partially responsible for the increased fractions of acicular ferrite for reasons which will now be discussed. From Fig. 1 it is apparent that a constant oxygen concentration of $250 \mathrm{ppm}$ is achieved with the addition of approximately $100 \mathrm{ppm}$ titanium. Further increases in titanium concentration do not decrease weld metal oxygen concentrations substantially. The mechanisms controlling weld pool deoxidization are complex and are reviewed in detail elsewhere. ${ }^{35)}$ A constant oxygen concentration implies that the volume fraction of oxide inclusions should remain essentially constant. Based on simple stoichiometric calculations, it is possible to convert the analytical weld metal oxygen and sulfur concentrations to an equivalent volume fraction of oxide and sulfide inclusions. Taking the solubility of sulfur in solid steel equal to $0.003 \mathrm{wt} \%$, the volume fraction of inclusions can be calculated in steel weld metals ${ }^{59,60)}$ :

$$
V_{\mathrm{v}}(\mathrm{cal})=10^{-2}[5.0(\mathrm{wt} \% \mathrm{O})+5.4(\mathrm{wt} \% \mathrm{~S}-0.003)] \ldots .
$$

The relationship between the volume fraction of inclusions, $V_{\mathrm{v}}$ and increasing amounts of weld metal titanium is shown in Fig. 6. The validity of Eq. (3) has

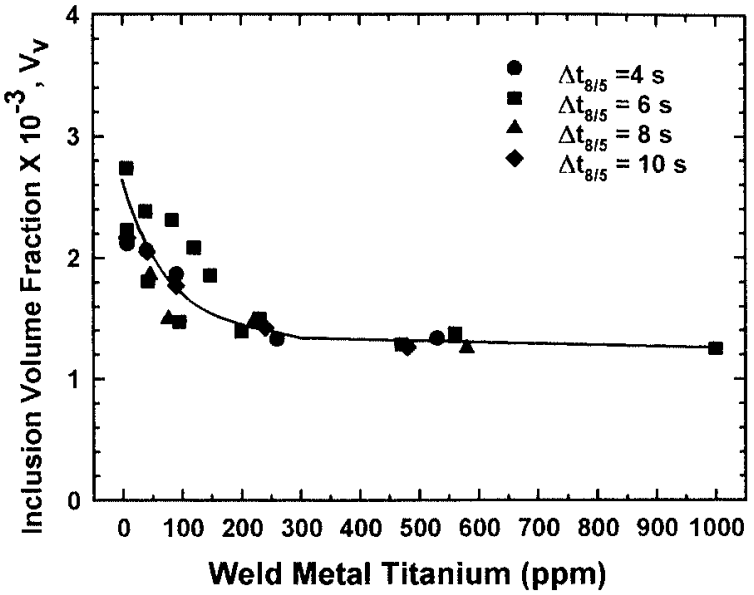

Fig. 6. Calculated inclusion volume fraction ${ }^{62)}$ as a function of weld metal titanium concentration.

been confirmed experimentally by comparison with microscopic assessment methods ${ }^{59}$ ) and the trend has been shown to not significantly change when strong deoxidizers are added and moderate changes in heat input are made. ${ }^{59)}$ As with the oxygen concentration, the calculated volume fraction of inclusions approaches a constant value at a titanium concentration of approximately $100 \mathrm{ppm}$. If titanium concentrations in excess of $100 \mathrm{ppm}$ do not result in the formation of additional oxide inclusions calculated in Fig. 6, it can be speculated that titanium will then be free to react with nitrogen to form titanium nitride. The formation of TiN in weld metals containing more than $100 \mathrm{ppm}$ titanium has been documented elsewhere. ${ }^{61)}$ At the present time however, the effect of titanium nitrides on the microstructures of high strength steel weld metals is uncertain. It is reported that TiN may be an effective heterogeneous nucleation site for acicular ferrite. ${ }^{62)}$ While the effect of oxide inclusions on the prior austenite grain size in weld metals which has been well documented, ${ }^{12)}$ similar studies on the pinning effects of TiN in weld metal are not well documented. The effectiveness of TiN in pinning prior austenite grain boundaries has been well documented in the base metal literature. ${ }^{63)}$

A large prior austenite grain size is favored in $\mathrm{C}-\mathrm{Mn}$ weld metals and has been shown to reduce the amount of grain boundary ferrite in addition to reducing the possibility that the grain interiors become "swamped" by aligned ferrite nucleated at austenite grain boundaries. ${ }^{12)}$ Although continuous films of grain boundary ferrite do not form in these alloyed weld metals, similar effects of small prior austenite grain sizes on the HSLA weld metal microstructures are expected; with small prior austenite grain sizes, bainitic ferrite will nucleate and grow to occupy the center of the austenite grains and compete with the growing acicular ferrite. In weld metals, prior austenite grain size has been shown to increase with decreasing oxygen concentration as the result of decreasing inclusion volume fraction ${ }^{59)}$ and the reduction of the number of very fine oxide inclusions. ${ }^{54)}$ From Figs. 3(a) to 5(a), it is apparent that a fine prior austenite grain size exists in weld metals with high oxygen concentrations, and predominantly aligned microstructures 
result. The mixed microstructures shown in Figs. 3(b) to 5 (b) consist primarily of acicular ferrite and martensite. The increased fraction of acicular ferrite may be attributed to the presence of titanium-rich inclusions and an increased prior austenite grain size. Increasing amounts of aligned ferrite are observed in the weld metals shown in Figs. 3(c) to 5(c) which contain titanium concentrations of approximately $90 \mathrm{ppm}$. This reversion to an aligned microstructure is speculated to be caused by smaller prior austenite grains, which are pinned by the formation of fine hypostoichiometric TiN precipitates. Fine austenite grains allow the bainitic ferrite which is nucleated at austenite grain boundaries to invade the grain interiors. With increasing titanium concentration, the diffusive flux of titanium (which controls Oswald ripening) results in coarser TiN particles. As the TiN ratio approaches and exceeds stoichiometry, the effectiveness of TiN in pinning austenite grains is reduced. Thus prior austenite grain size will again coarsen to a size controlled primarily by the oxide inclusions. Research to verify this speculative hypothesis is in progress.

Decreasing cooling rates (increasing $\Delta t_{8 / 5}$ ) resulted in a general coarsening of the weld metal microstructure. For example, Fig. 3(b) shows the extremely fine acicular ferrite/martensite microstructure produced with a cooling rate of $\Delta t_{8 / 5}=4 \mathrm{sec}$. Further decreases in cooling rates resulted in the formation of increasingly coarse microstructures as shown in Figs 4(b) and 5(b). The cause of this coarsening is most likely the reheating of as-deposited microstructures during the deposition of subsequent passes and the associated relatively low cooling rates.

Many welding studies quantify the relative volume fractions of microconstituent according to the IIW system in the top bead of a multiple pass weld while measuring toughness in the reheated weld metal. This approach assumes a direct correlation between the weld metal deposited in the last pass and the reheated weld metal. For the weld metals produced in this study, quantification of the top bead weld metal is discussed elsewhere. ${ }^{61)}$ Quantification of the reheated weld metal is difficult because the large thermal gradients produced during multiple pass welding produce corresponding gradients in microstructure. The relationship between as-deposited and reheated weld metal microstructures and properties in high strength steel weld metals has been investigated in another study ${ }^{61)}$ by depositing single beads of weld metal and then simulating the thermal cycles which are normally imposed during welding.

\subsection{Weld Metal Toughness}

Weld metals produced for this study had high toughness. In some CVN specimens, $100 \mathrm{~J}$ were absorbed at a temperature of $-70^{\circ} \mathrm{C}$. The toughness response of the weld metal to variations in titanium concentration and cooling rate were complex. Figure $7(\mathbf{a})$ shows the temperature at which $100 \mathrm{~J}$ were absorbed as a function of weld metal titanium concentration and interpass temperature. Excellent CVN toughness was found in weld metals containing titanium concentrations of either 30

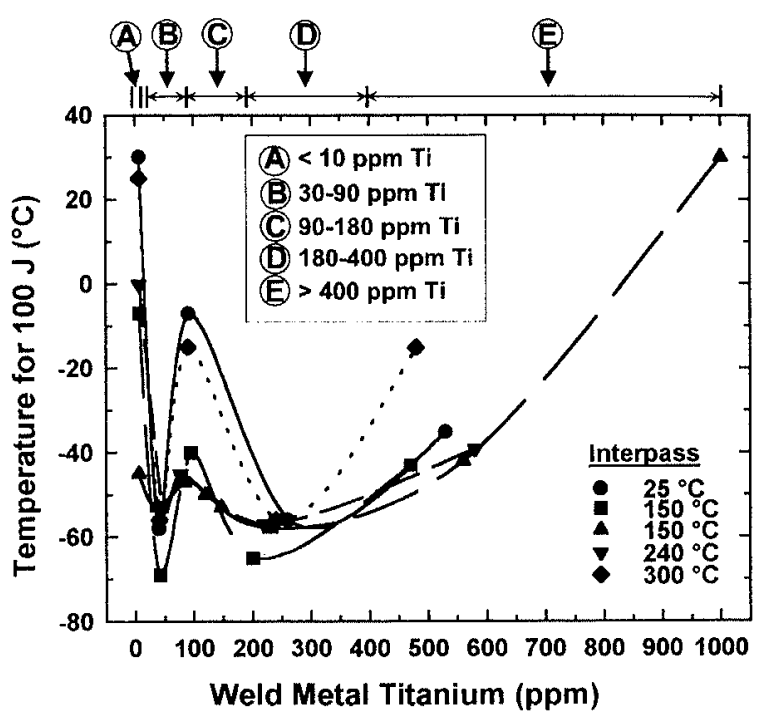

Fig. 7(a). Effect of weld metal titanium concentration on the temperature at which $100 \mathrm{~J}$ is absorbed.

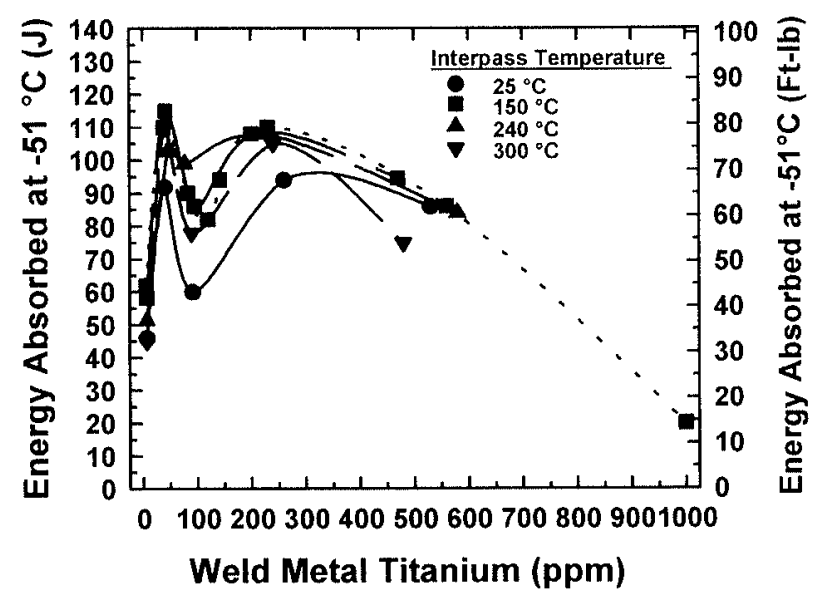

Fig. 7(b). Effect of weld metal titanium concentration on the energy absorbed at $-51^{\circ} \mathrm{C}$.

or $240 \mathrm{ppm}$, while degraded toughness was measured in weld metals containing titanium concentrations of less than $10 \mathrm{ppm}$, approximately $110 \mathrm{ppm}$, or greater than $400 \mathrm{ppm}$. Figure 7(b) shows that all weld metals produced except one containing $1000 \mathrm{ppm}$ titanium exceeded the AWS E10018 toughness requirement of $27 \mathrm{~J}$ at $-51^{\circ} \mathrm{C}^{1 \text { ) }}$ as measured in full size CVN specimens.

It is desirable to produce weld metals which are robust (i.e. manifesting properties which remain constant over a wide range of chemical compositions and cooling rates). Figure 7 (a) illustrates that, at least with respect to titanium concentration, it is difficult to determine which weld metals are robust. As shown in Fig. 7(a), toughness variations can be divided into five distinct regions as a function of titanium concentration: Region A; with poor toughness in welds containing less than 10 ppm titanium, Region B; where increasing titanium concentration from 30 to $90 \mathrm{ppm}$ resulted in a substantial increase in toughness, Region $\mathrm{C}$; in which degraded toughness resulted when titanium concentration ranged from approximately 90 to $180 \mathrm{ppm}$, Region D; where toughness improved once again for titanium concentrations ranging from 180 to $400 \mathrm{ppm}$, and Region E; where 
decreasing toughness was measured when titanium concentrations exceeded $400 \mathrm{ppm}$. Cooling rates produced by the various interpass temperatures have been directly determined in a previous study by Evans $^{28)}$ and can also be calculated using Eqs. (1) and (2) as discussed previously. Cooling rates $\left(\Delta t_{8 / 5}\right)$ of $4,6,8$, and $10 \mathrm{sec}$ correspond to interpass temperatures of $25,150,240$, and $300^{\circ} \mathrm{C}$ respectively.

Figure 8 shows the temperature at which $100 \mathrm{~J}$ were absorbed in standard CVN specimens, plotted as a function of cooling time, $\Delta t_{8 / 5}$, for weld metals with titanium compositions within the previously mentioned five regions. Welds containing less than $10 \mathrm{ppm}$ titanium (Region A) displayed the worst toughness independent of interpass temperature. Welds produced with titanium concentrations in Region C (90 to $180 \mathrm{ppm}$ ) and Region $\mathrm{E}(>400 \mathrm{ppm})$ possessed $100-\mathrm{J}$ temperatures ranging from -5 to $-54^{\circ} \mathrm{C}$ depending on cooling rate. Toughness of welds with titanium concentrations in Regions $\mathrm{A}, \mathrm{C}$, and $\mathrm{E}$ approached a maximum when the cooling time, $\Delta t_{8 / 5}$, was approximately $6 \mathrm{sec}$. Weld metals with titanium concentrations in Regions B ( 30 to $90 \mathrm{ppm}$ ) and $\mathrm{D}$ (180 to $400 \mathrm{ppm}$ ) manifested the best toughness, and toughness was essentially independent of cooling rate.

Close inspection of Fig. 8 shows that welds produced with titanium concentrations in Region D are the most robust of all and experienced essentially no change in toughness with increasing cooling rate. The toughness of weld metals in Region $D$ is insensitive to changes in cooling rate, and the range of titanium concentrations which produce high toughness is large. In this region, prior austenite grain size most likely remains constant as discussed previously; the volume fraction of oxide inclusions remains constant and the effectiveness of TiN precipitates in pinning austenite grain boundaries decreases with increasing titanium concentrations. Thus, a large prior austenite grain size which remains essentially constant throughout this range is expected.

Further increases of titanium to levels exceeding $400 \mathrm{ppm}$ resulted in deteriorated toughness. This observation has been confirmed by $\mathrm{Oh}$. et al. ${ }^{14)}$ who varied titanium concentration in $\mathrm{C}-\mathrm{Mn}$ weld metals

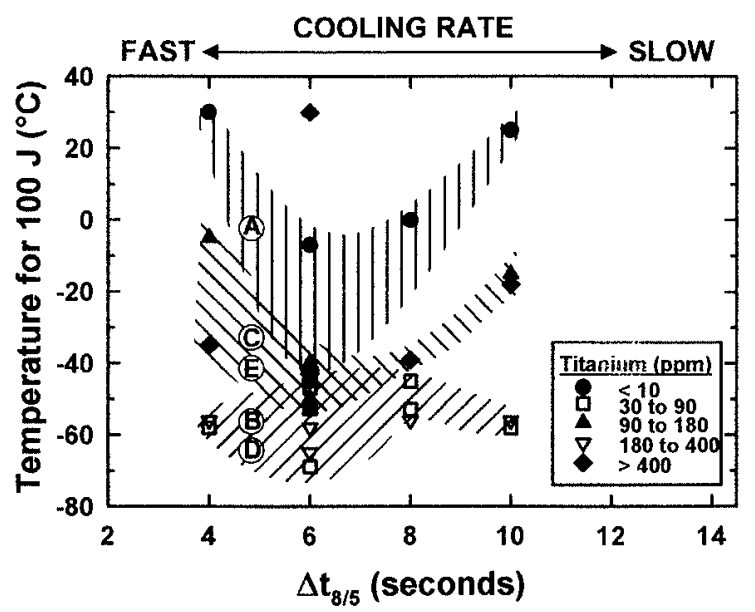

Fig. 8. Effect of weld metal cooling rate and weld metal titanium concentration on the temperature at which $100 \mathrm{~J}$ is absorbed. produced using flux-cored electrodes. Pokhodyna et al. ${ }^{64)}$ found that toughness deteriorated with high titanium concentrations $(\sim 400 \mathrm{ppm})$ and that titanium segregated during solidification, causing localized regions with high titanium concentration. In addition to the segregation of nickel and manganese, segregation of titanium may be responsible for the banding shown in Figs. 3(e) to 5(e), and thus may contribute to the poor toughness.

\subsection{Weld Metal Tensile Properties}

Figure 9 shows the influence of $\Delta t_{8 / 5}$ on the weld metal yield strength. Weld metal yield strengths decreased with increasing $\Delta t_{8 / 5}$ (decreasing cooling rate), and all welds with $\Delta t_{8 / 5}$ less than $8 \mathrm{sec}$ exceeded the minimum tensile strength requirements of $600 \mathrm{MPa}$ proposed by the American Welding Society for E10018-M type electrodes. The decrease in strength levels with decreasing cooling rates is attributed to the coarsening of the reheated weld metal as shown in Figs. 3 to 5. For a given cooling rate, there are subtle variations in the strength as a function of chemical composition. Strength levels were observed to increase by as much as $150 \mathrm{MPa}$ when titanium concentration was increased, a factor attributed to microstructural refinement and precipitation. ${ }^{61)}$ Figure 10 shows the yield strength to tensile strength ratios as a function of cooling rate. Weld metal undermatching

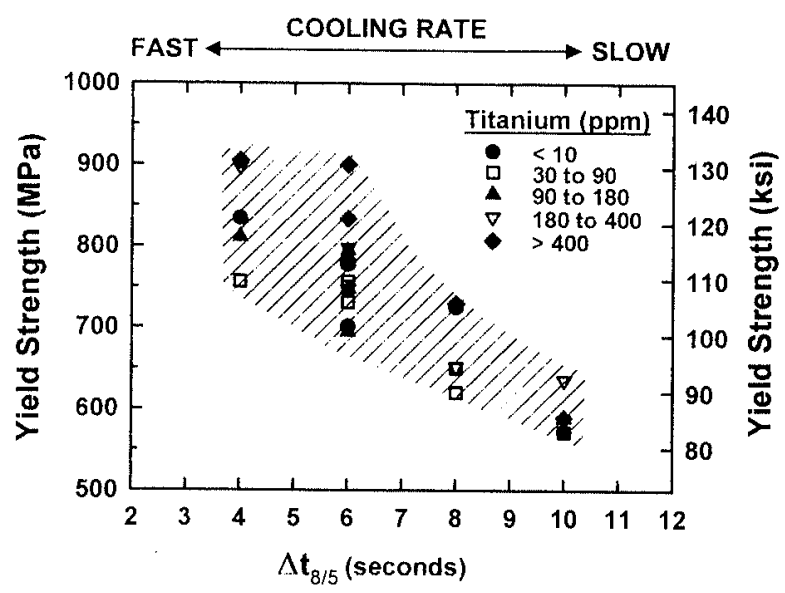

Fig. 9. The effect of cooling rate on weld metal yield strength.

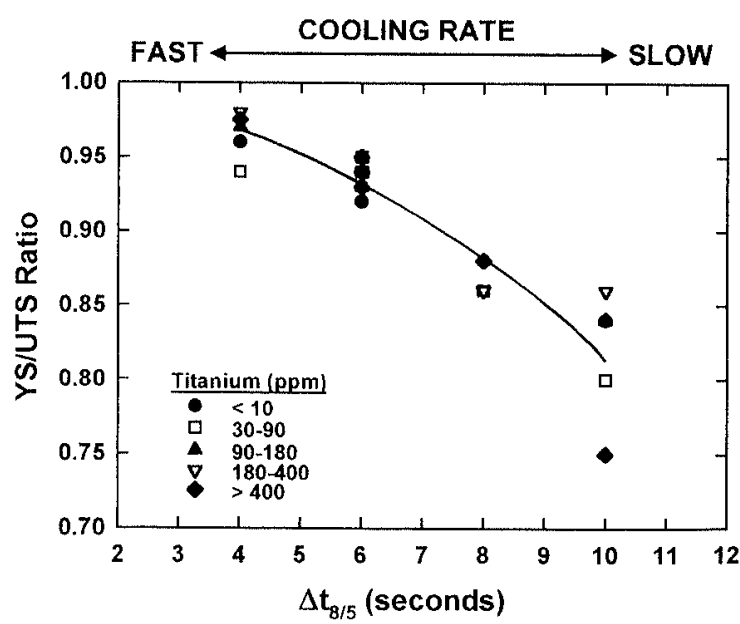

Fig. 10. The inffuence on cooling rate on the yield strength to ultimate tensile strength ratio. 


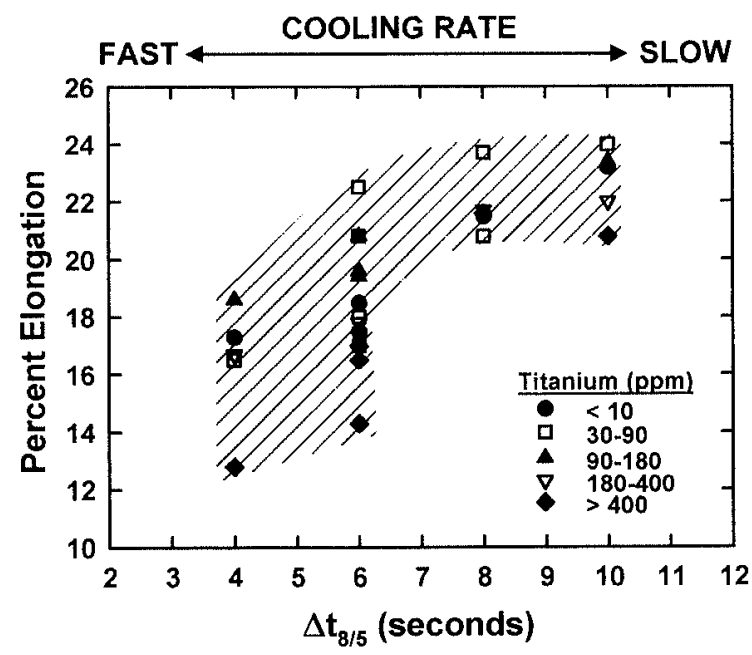

Fig. 11. The influence of cooling rate on weld metal elongation.

to join higher strength base metals would require YS/UTS ratios exceeding 0.85 . While ratios of 0.90 are common in most HSLA weld metals, the YS/UTS ratio in these weld metals decreases with increasing $\Delta t_{8 / 5}$. An acceptable ratio was observed in the weld metals when $\Delta t_{8 / 5}$ exceeded six seconds. The decrease in YS/UTS ratio with decreasing cooling rate for these weld metals is attributed to decreasing martensite fractions in the weld metal produced with longer cooling times. ${ }^{61)}$

The influence of cooling rate on weld metal elongation is shown in Fig. 11. Percent elongation increased with increasing $\Delta t_{8 / 5}$, with most of the weld metals exceeding the elongation requirement of $16 \%$ as specified by AWS for E10018 type electrodes. ${ }^{1)}$ However, only weld metals deposited with $\Delta t_{8 / 5}$ greater than $8 \mathrm{sec}$ exhibited ductility exceeding the $20 \%$ elongation required for E10018-M type of electrodes. ${ }^{11}$ As with yield strength, ductility was found to vary as a function of titanium concentration, with weld metals produced with approximately 30 to $90 \mathrm{ppm}$ titanium generally exhibiting the highest ductility.

\section{Conclusions}

(1) Robust weld metals with high strength and toughness were produced when titanium concentrations of 180 to $400 \mathrm{ppm}$ were added to a base chemical composition of low carbon-1.5Mn-3Ni-0.5Mo steel.

(2) Deteriorated weld metal toughness was observed when weld metal titanium concentrations were less than $10 \mathrm{ppm}, 90$ to $180 \mathrm{ppm}$, or more than $400 \mathrm{ppm}$. Despite the degraded toughness of weld metals with these titanium compositions, increased toughness in these weld metals occurred when $\Delta t_{8 / 5}$ was approximately $6 \mathrm{sec}$, which corresponds to an interpass temperature of $150^{\circ} \mathrm{C}$ at a nominal heat input of $1 \mathrm{~kJ} \mathrm{~mm}^{-1}$.

(3) Changes in the low carbon HSLA steel weld metal microstructures were complex. Additional research is required to adequately characterize the competitive phase transformations and resultant microstructures.

(4) Decreases in yield strength with decreases in cooling rate correlated consistently with coarsening of the reheated weld metal microstructures.

\section{Acknowledgments}

Support from the AWS Foundation Fellowship, Center for Welding, Joining, and Coatings Research; Colorado School of Mines, and Oerlikon Welding Ltd. is gratefully acknowledged.

\section{REFERENCES}

1) AWS, Specification for Low Alloy Steel Covered Arc Welding Electrodes-AWS 5.5-81, American Welding Society, Miami, Florida, (1981).

2) G. R. Edwards and S. Liu: Symp. Proc. on Advances in Welding Metallurgy, First US-Japan Symposium-AWS/JWS/JWES, San Francisco, U.S.A. and Yokohama, Japan, (1990), 215.

3) C. W. Ramsay: Colorado School of Mines Ph. D. Thesis, Colorado School of Mines, Golden, Colorado, U.S.A., (1989).

4) P. T. Oldland, C. W. Ramsay, D. K. Matlock and D. L. Olson: Weld. J., 68 (1989), 158s.

5) A. A. B. Sugden and H. K. D. H. Bhadeshia: Metall. Trans., 19 (1988), 1597.

6) N. Hannerz and Z. Zhou: OMAE-Materials Engineering ASME, 3B (1990), 769.

7) J. A. Gianetto, N. J. G. Smith, J. T. McGrath and J. T. Bowker: Weld. J., 71 (1992), $407 \mathrm{~s}$.

8) J. A. Gianetto, N. J. G. Smith, D. E. Dolan and J. T. McGrath: Can. Metall. Q., 31 (1994), 35.

9) A. O. Kluken, M. I. Onsøien, O. Akselsen and G. Rørvik: Join. Sci., 1 (1991), 14.

10) M. Q. Johnson: Colorado School of Mines M.S. Thesis, Colorado School of Mines, Golden, Colorado, U.S.A., (1993).

11) D. A. Flemings: Colorado School of Mines M. S. Thesis, Colorado School of Mines, Golden, Colorado, U.S.A., (1993).

12) Ø. Grong and D. K. Matlock: Int. Met. Rev., 31 (1986), 27.

13) S. Ohkita, H. Homma, S. Taushima and N. Mori: IIW-Doc. II-1070-86, American Council, AWS, Miami, Florida, U.S.A., (1986).

14) D. W. Oh, D. L. Olson and R. H. Frost: Weld. J., 69 (1990), $151 \mathrm{~s}$.

15) G. M. Evans: Weld. J., 61 (1982), 125s.

16) T. H. North, H. B. Bell, A. Koukabi and I. Craig: Weld. J., 58 (1979), 343s.

17) N. Mori, H. Homma, S. Ohkita and K. Asano: IIW Doc. IX-1158-80, American Council, AWS, Miami, Florida, U.S.A., $(1980)$.

18) N. Mori, H. Homma, S. Ohkita and M. Wakabayashi: IIW Doc. IX-1196-81, American Council, AWS, Miami, Florida, U.S.A., (1981).

19) N. Mori, H. Homma, M. Wakabayashi and S. Ohkita: IIW Doc. IX-980-82, American Council, AWS, Miami, Florida, U.S.A., (1982).

20) H. Suzuki, Y. Sogo, R. Iwanaga and Y. Ohno: IIW Doc. IX-1314-84, American Council, AWS, Miami, Florida, U.S.A., (1984).

21) K. Yamamoto, S. Matsuda, T. Haze, R. Chjiiwa and H. Mimura: Symp. Residual and Unspecified Elements in Steel, ASTM, (1987).

22) H. Homma, S. Okita, S. Matsuda and K. Yamamoto: Weld. J., 66 (1987), 301s

23) ASM Handbook Vol. 6, 662, ASM International, Metals Park, Ohio, U.S.A., (1993)

24) AWS, Structural Welding Code-Steel-ANSI/AWS D1.1-92, American Welding Society, Miami, Florida, U.S.A., (1992).

25) G. M. Evans: Weld. World, 31 (1993), 12.

26) G. M. Evans: IIW Doc. IX-1765-94, American Council, AWS, Miami, Florida, U.S.A., (1994).

27) ISO 2560; Covered Electrodes for Manual Arc Welding of Mild and Low Alloy Steel-code of Symbols for Identification, (1973).

28) G. M. Evans: Weld. Rev., 1 (1982), 14.

29) Y. Ito and K. Besseyo: IIW Doc. IX-567, American Council, AWS, Miami, Florida, U.S.A., (1968).

30) G. M. Evans: Weld. J., 65 (1986), 325s.

31) D. Rosenthal: Trans. ASME, 68 (1946), 849. 
32) C. M. Adams, Jr.: Weld. J., (1958), $210 \mathrm{~s}$.

33) K. Easterling: Introduction to the Physical Metallurgy of Welding, (1992), Pub. Butterworth-Heinemann, Oxford, UK, (1992).

34) L. E. Svensson: Control of Microstructures and Properties in Steel Arc Welds, CRC Press, (1994).

35) $\varnothing$. Grong: Metallurgical Modeling of Welding, Institute of Materials, (1994).

36) G. M. Evans: Weld. J., 61 (1982), 125s.

37) D. J. Abson: IIW Doc. IX-1533-88, American Council, AWS, Miami, Florida, U.S.A., (1988).

38) C. A. Dubé, H. I. Aaronson and R. F. Mhel: Rev. Met., 55 (1958), 201.

39) D. J. Abson: Welding Institute Report No. 9582/1/92, (1992).

40) G. Krauss and S. W. Thompson: ISIJ Int., 35 (1995), 1222.

41) H. I. Aaronson: The Mechanism of Phase Transformations in Crystalline Solids, The Institute of Metals, London, (1969), 270.

42) W. T. Reynolds, Jr., H. I. Aaronson and G. Spanos: Mater. Trans., JIM, 32 (199I), 737.

43) L. J. Habraken and M. Economopolus: Transformation and Hardenability in Steels, Climax Molybdenum Co., Ann Arbor, MI, (1967), 69.

44) Y. Ohmori, H. Ohtani and T. Kunitake: Trans ISU, 11 (1971), 250 .

45) H. Ohtani, S. Okaguchi, Y. Fujishiro and Y. Ohmori: Metall. Trans, $21 \mathrm{~A}$ (1990), 877.

46) B. L. Bramfitt and J. G. Speer: Metall Trans., 21A (1990), 817.

47) T. Araki, M. Enomoto and K. Shibota: Mater. Trans. JIM, 32 (1991), 729.

48) Atlas for Bainitic Microstructures, Vol. 1, ISIJ, Tokyo, (1992).

49) Y. E. Smith, A. P. Coldren and R. L. Cryderman: Toward
Improved Ductility and Toughness, Climax Molybdenum Company, Ann Arbor, MI, (1971), 119.

50) S. W. Thompson, D. J. Colvin and G. Krauss: Metall. Trans., 21A (1990), 1493.

51) P. Deb, K. D. Challenger and A. E. Therrien: Metall. Trans., 18A (1987), 987.

52) K. K. D. H. Bhadeshia and L. E. Svensson: J. Mater. Sci, 24 (1989), 3180.

53) G. M. Evans: Weld J., 71 (1992), 447s.

54) S. Liu: In Ferrous Alloy Weldments, ed. by D. L. Olson and T. H. North, Zurich (Switzerland), Trans. Tech. Publications, (1992), 1.

55) Ø. Grong and A. O. Kluken: In Ferrous Alloy Weldments, ed. by D. L. Olson and T. H. North, Zurich (Switzerland), Trans. Tech. Publications, (1992), 21.

56) A. R. Mills, G. Thewlis and J. A. Whiteman: Mater. Sci. Technol., 3 (1987), 105I.

57) R. A. Farrar and P. L. Harrison: J. Mater Sci., 22 (1987), 3812.

58) P. L. Harrison and R. A. Farrar: Int. Met. Rev., 1989 (1989), 35

59) A. O. Kluken and Ø. Grong: Metall. Trans., 20A (1989), 1335.

60) A. G. Franklin: J. Iron Steel Inst., 207 (1969), 181.

61) M. Q. Johnson: Colorado School of Mines $\mathrm{Ph}$. D. Thesis, Colorado School of Mines, Golden, Colorado, U.S.A., (1995).

62) Ø. Grong, A. O. Kluken, H. K. Nylund, A. L. Dons, A. L and J. Hjelen: Metall. Trans., 22A (1995), 657.

63) A. J. Deardo, C. I. Garcia and E. J. Palmiere: ASM Handbook, Heat Treating, 4 (1991), 237.

64) I. K. Pokhodnya, A. O. Korsun and Y. Y. Meshkov: IIW Doc. II-A-768-89, American Council, AWS, Miami, Florida, U.S.A., (1989). 